\title{
PENDAMPINGAN KETERAMPILAN MENGOLAH PRODUK SAINS (SUSU FERMENTASI VARIANS BUAH) MENGGUNAKAN METODE EKSPERIMEN MELALUI AKTIVITAS PRAKTIKUM SEKOLAH DALAM MENINGKATKAN ACADEMIC ENTREPRENEUR
}

\author{
Dyah Ayu Fajarianingtyas ${ }^{1}$, Jefri Nur Hidayat ${ }^{2}$ \\ ${ }^{1,2)}$ Fakultas Keguruan dan Ilmu Pendidikan Universitas Wiraraja \\ Email: azrilarkan@gmail.com ${ }^{1)}$, jefri.nh@wiraraja.ac.id ${ }^{2)}$
}

\begin{abstract}
ABSTRAK
Nama mitra/kelompok sasaran adalah SD Luqman Al Hakim yang terletak di di Jalan Payudan Barat Nomor 3 Sumenep. Masalah mitra/kelompok sasaran berdasarkan analisis situasi adalah dari hasil observasi oleh Tim PKM bulan Januari tahun 2019 diketahui bahwa (1) ketersediaan alat dan bahan di kelompok mitra belum memenuhi standar IPA Sekolah untuk melakukan metode eksperimen di bidang Sains; (2) keterampilan proses siswa belum tergali secara optimal karena jarang melakukan metode eksperimen untuk membuktikan konsep IPA. Salah satu solusi/target luaran yang ingin dicapai adalah perlu dilakukan Pendampingan Pelatihan Produk Sains Melalui Aktivitas Praktikum Sekolah. Melalui Program Pelatihan ini, maka luaran dan tujuan yang diharapkan adalah adanya publikasi jurnal Abdiraja dan peningkatan keterampilan/skill dalam mengolah pembuatan susu fermentasi dari berbagai varian rasa buah sebagai produk sains.

Metode pendekatan yang ditawarkan untuk menyelesaikan persoalan mitra adalah metode pendidikan masyarakat melalui pendampingan keterampilan mengolah Produk Sains (susu fermentasi Varians Buah) Menggunakan Metode Eksperimen Melalui Aktivitas Praktikum Sekolah. Pelatihan dilakukan dengan menggunakan metode eksperimen. Metode eksperimen sebagai cara belajar mengajar yang melibatkan siswa dengan mengalami serta membuktikan sendiri proses dan hasil percobaan (Putra, 2013). SD Luqman Al Hakim secara kelompok akan melakukan praktikum produk Sains (susu fermentasi Varians Buah) yang akan didampingi oleh Tim PKM. Manfaat yang dirasakan oleh kelompok sasaran adalah keterampilan siswa menjadi terasah karena siswa melakukan metode eksperimen untuk membuat (susu fermentasi Varians Buah). Siswa sangat antusias melakukan experiment susu fermentasi varians buah. Hasil rata-rata respon sebesar 96\%. Pembelajaran berbasis entrepreneurship memberikan memberikan bekal kewirausahaan dengan tetap memperhatikan bakat, minat, dan suasana menyenangkan.
\end{abstract}

Kata kunci : Metode Eksperimen, susu fermentasi Varians Buah

\section{PENDAHULUAN}

Kondisi kelompok sasaran/nama mitra yang dilibatkan dalam kegiatan Pengabdian Kepada Masyarakat yaitu SD Luqman Al Hakim yang terletak di Desa Pabean, saat ini memiliki berbagai kegiatan baik akademis maupun non akademis. Salah satu kegiatan non akademis yang mendukung
Academic Entrepreneur dalam mempersiapkan diri menghadapi era digital yaitu kegiatan bina prestasi di SD Luqman Al Hakim pada saat KBM. Kegiatan ini merupakan kegiatan yang mengeksplorasi kemampuan bakat siswa di bidang Sains. Pemilihan mitra didasarkan pertimbangan bahwa SD Luqman Al Hakim telah aktif 
berpartisipasi dan selalu langganan juara AKS dalam kegiatan AKS (Asah Kreatifitas Sains) tingkat Madura yang diselenggarakan FKIP. Oleh karena itu, SD Luqman Al Hakim berkeinginan untuk adanya tindak lanjut kerja sama dalam aktivitas Sains. Tujuan didirikan kegiatan bina prestasi meliputi (1) menggali potensi siswa di bidang Sains; mengembangkan kemampuan berpikir kritis dan berpikir kreatif; (3) berpartisipasi dalam berbagai event di bidang Sains baik tikat lokal hingga Internasional. Pihak sekolah menyelenggarakan kegiatan pembinaan setiap 2-3 kali seminggu untuk setiap jenjang kelas.

Permasalahan yang dihadapi oleh kelompok sasaran/mitra adalah berdasarkan hasil observasi oleh Tim PKM bulan Januari tahun 2019 diketahui bahwa (1) ketersediaan alat dan bahan di kelompok mitra belum memenuhi standar IPA Sekolah untuk melakukan metode eksperimen di bidang Sains; (2) keterampilan proses siswa belum tergali secara optimal karena jarang dilakukan metode eksperimen untuk membuktikan konsep IPA. Keterampilan memiliki keterkaitan erat dengan kemampuan seseorang dalam mengembangkan ide, memilih, menggunakan peralatan ataupun bahan, serta keterampilan dalam melakukan teknik kerja (Prastowo, 2011). Keterampilan proses merupakan kemampuan dari aspek kognitif dan psikomotor yang diperoleh melalui latihan secara terarah untuk dapat digunakan dalam menemukan, mengembangkan, dan melakukan penyangkalan terhadap suatu penemuan berdasarkan teori yang ada sebelumnya (Trianto, 2012). Kemampuan yang terlatih terus-menerus akan menjadi kebiasaan yang dapat meningkatkan keterampilan suatu individu. Solusi yang ditawarkan untuk permasalahan mitra adalah pendampingan keterampilan mengolah Susu fermentasi dari berbagai varian rasa buah sebagai produk sains relevan dengan materi IPA jenjang kelas 4 sampai 6 tingkat SD.

\section{METODE}

Metode pendekatan yang ditawarkan untuk menyelesaikan persoalan mitra adalah metode pendidikan masyakat melalui pendampingan keterampilan mengolah Produk Sains (susu fermentasi Varians Buah) Menggunakan Eksperimen. Peserta pelatihan terdiri atas siswa bina prestasi SD Luqman al Hakim. Pada tahap ini peserta pelatihan melakukan kegiatan experiment didampingi Tim PPM. Langkah (1) menyiapkan bahan susu fermentasi varians buah meliputi Susu UHT original tanpa gula $(1000 \mathrm{ml})$, Starter yakult, Varians buah (Naga dan Melon), Tahap (2) Masukkan susu dan yakult ke dalam wadah dengan perbandingan ( 2 botol yakult untuk 1 liter susu UHT) kemudian diinkubasi selama 48 jam di suhu ruang. Setelah 24 jam sehingga campuran susu berubah menjadi yakult; Tahap (3) adalah tambahkan varians buah (naga dan melon) sesuai selera; campur susu dan buah menggunakan blender lalu saring, Tahap (4) adalah susu fermentasi varians buah siap dikonsumsi dan lebih nikmat jika dikonsumsi dalam keadaan dingin atau ditambah es batu.

Pelaksanaan program pengabdian masyarakat telah dilaksanakan untuk mitra kelompok siswa bina prestasi SD Luqman Al Hakim Jalan Payudan Barat Nomor 3 Sumenep sebagai peserta pelatihan pengolahan susu fermentasi varians buah. Adapun hasil kegiatan sebagai berikut.

Peserta pelatihan terdiri atas siswa bina prestasi SD Luqman al Hakim. Pada tahap ini peserta pelatihan melakukan kegiatan experiment didampingi Tim PPM. Langkah (1) menyiapkan bahan susu 
fermentasi varians buah meliputi Susu UHT original tanpa gula (1000 ml), Starter yakult, Varians buah (Naga dan Melon), tampak pada Gambar 1 sebagai berikut.

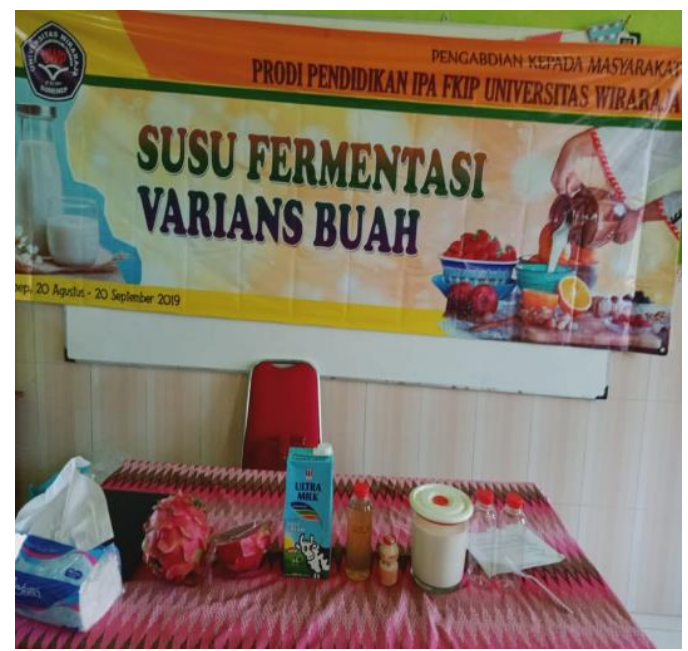

\section{Gambar 1. Persiapan bahan susu fermentasi varians buah}

Tahap selanjutnya (2) Masukkan susu dan yakult ke dalam wadah dengan perbandingan ( 2 botol yakult untuk 1 liter susu UHT) kemudian diinkubasi selama 48 jam di suhu ruang Setelah 24 jam sehingga campuran susu berubah menjadi yakult, adalah tampak pada Gambar 2 sebagai berikut.

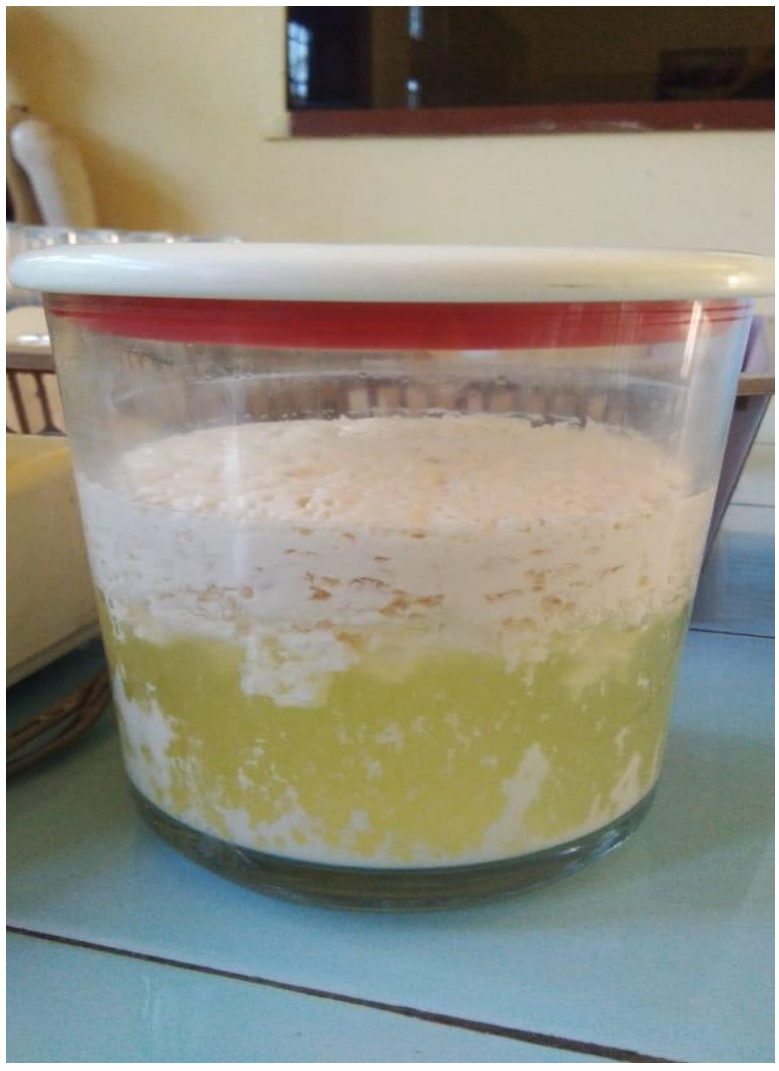

Gambar 2. Hasil inkubasi selama 48 jam

Tahap berikutnya adalah tambahkan varians buah (naga dan melon) sesuai selera; campur susu dan buah menggunakan blender lalu saring, seperti pada Gambar 3, 4 dan 5 berikut ini.

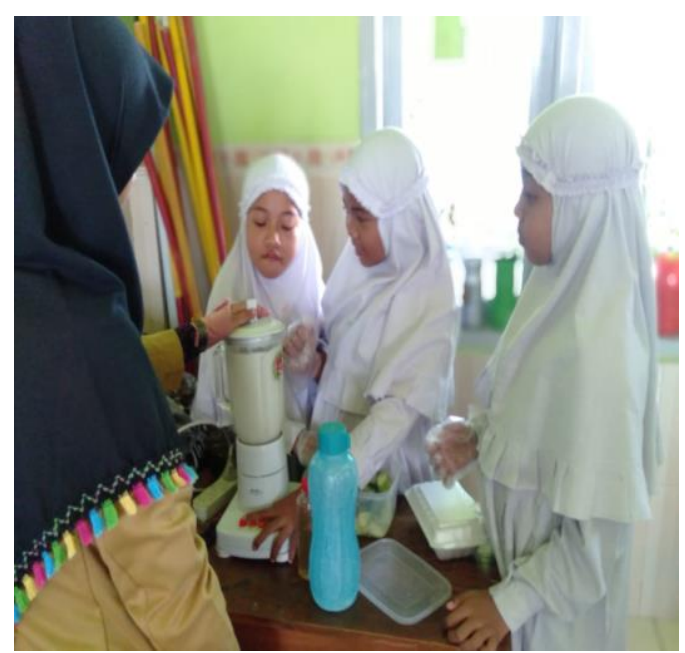

Gambar 3. Proses mencampur susu dengan buah menggunakan blender 


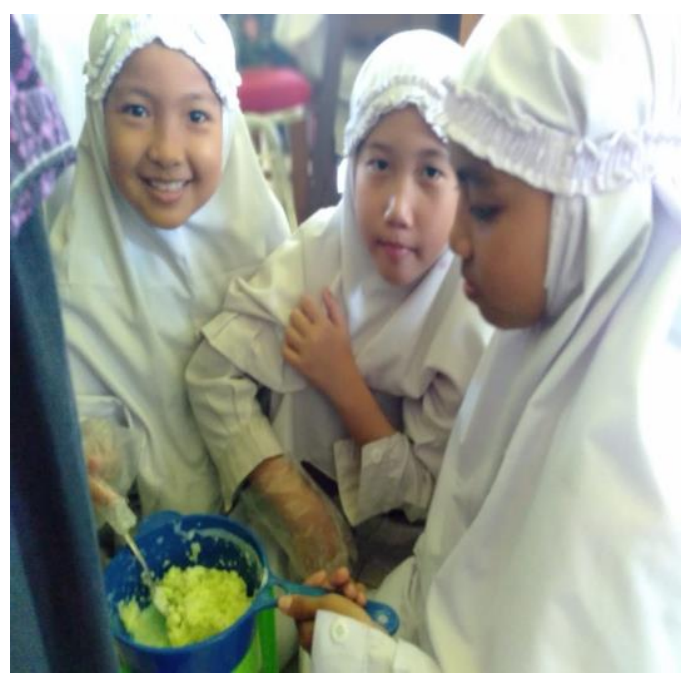

Gambar 4. Proses menyaring

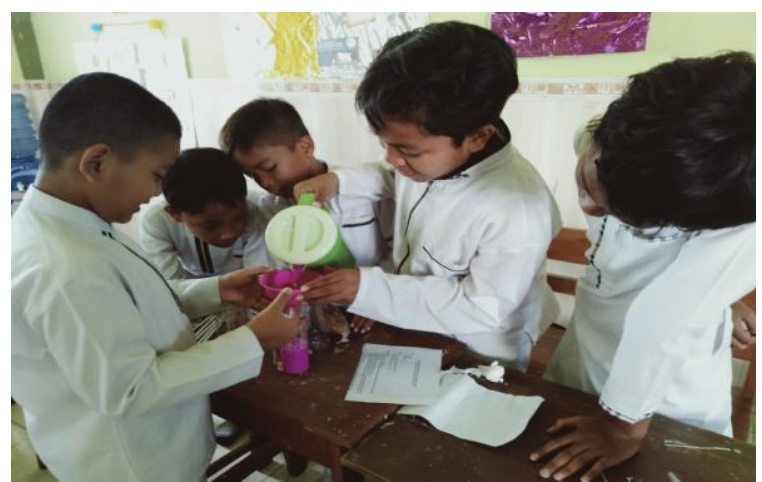

Gambar 5. Proses menuangkan susu fermentasi ke dalam botol

Langkah terakhir adalah susu fermentasi varians buah siap dikonsumsi dan lebih nikmat jika dikonsumsi dalam keadaan dingin atau ditambah es batu seperti pada Gambar 6 berikut ini.

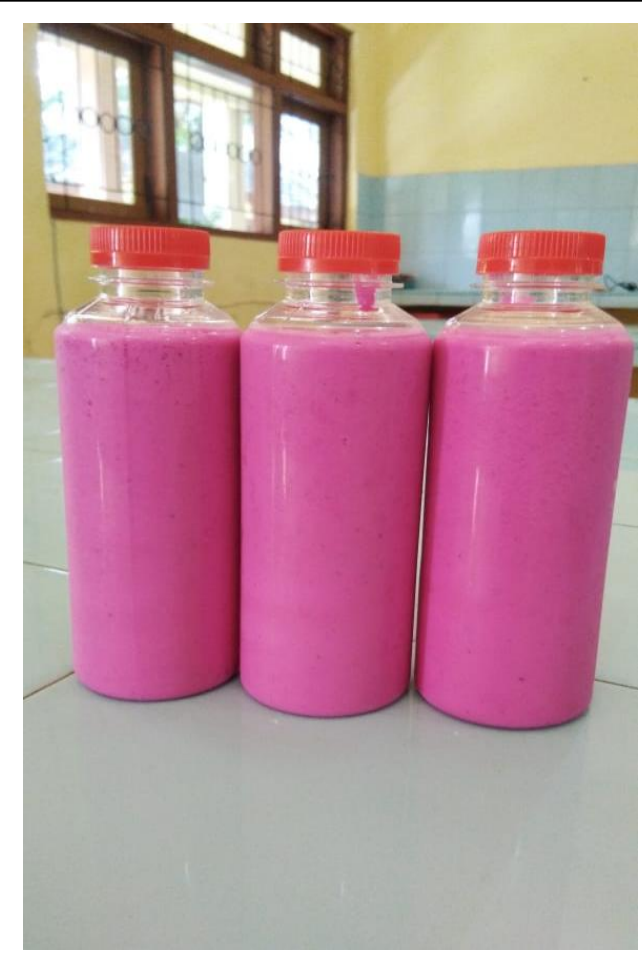

\section{Gambar 6. Susu Fermentasi buah Naga Merah}

Buah naga merah (Hylocereus polyrhizus) merupakan jenis buah tropis yang mudah ditemukan di Indonesia. Memiliki warna merah keunguan serta rasanya yang manis keasaman sehingga menjadi primadona bagi sebagian kalangan masyarakat. Buah naga merah dijadikan dalam bentuk sari buah dalam proses pembuatan yoghurt campuran susu sapi dan kacang merah bertujuan untuk mendapatkan konsentrasi yang lebih kental dan tidak adanya ampas yang terbawa. Selain diharapkan mampu untuk memperbaiki sifat sensoris, menurut (Kartikasari, 2014) buah naga merah yang mengandung antioksidan yang sangat tinggi yaitu berupa kandungan Vitamin C sebesar 8 - $9 \mathrm{mg}$ dalam per $100 \mathrm{~g}$ buah naga merah yang diharapkan mampu membuat produk yoghurt yang dihasilkan menjadi sumber antioksidan yang baik untuk tubuh. 


\section{HASIL DAN PEMBAHASAN}

Hasil yang didapatkan dari pelaksanaan pelatihan ini adalah siswa sangat antusias melakukan experiment susu fermentasi varians buah. Hasil rata-rata respon sebesar 96\%. Adapun indicator pelaksanaan kegiatan menunjukkan pada indicator menyatakan senang melakukan experiment ini sebesar 97\%; indicator bahwa experiment ini dapat membantu siswa mengerti pelajaran IPA sebesar 92\%; indicator bahwa experiment ini dapat mendukung siswa memahami pelajaran IPA sebesar 94\%; indicator kemudahan melakukan experiment susu fermentasi varians buah sebesar 95\%; indicator yang menyatakan bahwa tim PPM menyajikan urutan experiment sebesar 95\%; dan indicator kejelasan langkah-langkah experiment sebesar $100 \%$.

Kegiatan pengabdian kepada masyarakat untuk mitra Bina prestasi sebagai peserta pelatihan mendapat sambutan yang sangat baik. Peserta pelatihan ini diharapkan dapat meningkatkan jiwa wirausaha muda dalam experiment susu fermentasi varians buah. Jiwa entrepreneur harus sedini mungkin ditanamkan pada siswa, mengingat jiwa seorang entrepreneur akan membuat seseorang bermental baja dan tangguh sehingga dapat menciptakan sumber daya yang berkualitas. Pembelajaran berbasis entrepreneurship memberikan memberikan bekal kewirausahaan dengan tetap memperhatikan bakat, minat, dan suasana menyenangkan (Widiasworo, 2017).

Faktor pendorong dalam kegiatan pelatihan adalah: (1). Peran mitra sebagai peserta sangat aktif pada saat pelatihan berlangsung; (2) Respon siswa dan guru bina Prestasi sebagai mitra sangat antusias; (3) Fasilitas tempat kegiatan dan jadwal kegiatan yang mendapat izin dari pihak sekolah maupun wali murid; (4) tersedianya sarana dan prasarana di Laboratorium IPA Terpadu telah memenuhi standar IPA sekolah; dan (5) keterampilan mahasiswa IPA sebagai tutor pendampingan yang telah memiliki sertifikat asisten laboratorium IPA Terpadu.

Faktor penghambat diantaranya adalah: (1) pemilihan alat dan bahan disesuaikan dengan jenjang anak sekolah yaitu menghindari penggunaan kompor untuk experiment susu bubuk maupun susu segar.

Hasil penelitian (Kartikasari \& Nisa, 2014), kombinasi perlakuan yang memberikan pengaruh terbaik dari yoghurt dengan penambahan sari buah sirsak dan lama fermentasi adalah penambahan sari buah sirsak $10 \%$ dan lama fermentsi 12 jam. Hasil penelitian (Putri, 2019) Penggunaan SBNM dengan konsentrasi 15\% merupakan produk yang memiliki karakteristik terbaik dengan kriteria kadar total asam laktat 1,22\%, pH 4,41, kandungan Vitamin C $1,11 \mathrm{mg} / 100 \mathrm{~g}$. Hasil penelitian (Ulva Dianasaril \& Maruddin, 2018) semakin lama inkubasi maka total asam laktat semakin meningkat. Peningkatan total asam laktat maka akan menurunkan nilai $\mathrm{pH}$. Nilai $\mathrm{pH}$ yang semakin menurun yaitu semakin asam akan menyebabkan kecerahan pigmen antosianin semakin meningkat.

\section{SIMPULAN}

Pelaksanaan program pengabdian kepada masyarakat berupa pelatihan susu fermentasi varians buah dapat disimpulkan berhasil yang ditunjukkan antara lain sebagai berikut: (1) respon positif dari mitra adalah sebagai peserta pelatihan sebesar $96 \%$, serta (2) adanya peningkatan keterampilan/skill entrepreneurship melalui kegiatan experiment susu fermentasi varians. Rekomendasi yang 
dapat diberikan implementasi pelatihan susu fermentasi varians adalah kegiatan pelatihan ini dapat berlangsung secara periodik untuk menunjang Prodi Pendidikan IPA. Keberlanjutan program dapat dilakukan oleh SD Luqman Al Hakim dalam kegiatan Pembinaan Belajar sains dan bina prestasi.

\section{UCAPAN TERIMA KASIH}

Ucapan terima kasih kepada mitra SD Luqman Al-hakim dan pihak yang turut membantu.

\section{DAFTAR PUSTAKA}

Desroiser, N. W. (1988). Teknologi Pengolahan Pangan. Penerbit Universitas Indonesia, Jakarta.

Kartikasari, D. I. (2014). The Influence of Soursop Juice Addition and Fermentation Period toward Physical Chemistry Properties of Yoghurt. Jurnal Pangan Dan Agroindustri, Vol. 2 No, p.239-248.

Kartikasari, D. I., \& Nisa, F. C. (2014). PENGARUH PENAMBAHAN SARI BUAH SIRSAK DAN LAMA FERMENTASI TERHADAP KARAKTERISTIK FISIK DAN KIMIA YOGHURT The Influence of Soursop Juice Addition and Fermentation Period toward Physical Chemistry Properties of
Yoghurt. Jurnal Pangan Dan Agroindustri Vol., 2(4), 239-248.

Prastowo, A. (2011). Panduan Kreatif Membuat Bahan Ajar. Jogjakarta: Diva Press.

Putra, S. R. (2013). Desain belajar mengajar kreatif berbasis sains. Yogyakarta: Diva Press.

Putri, D. C. L. A. (2019). The Effect of Adding Red Dragon Fruit (Hylocereus Polyrhizus) Juice for The Characteristics of Yogurt Mixed Milk and Red Beans (Phaseolus Vulgaris). Jurnal Ilmu Dan Teknologi Pangan. Vol. 8, No.1, 8-17, Vol. 8, No, 8-17.

Sardjoko. (1996). No Title. In Bioteknologi, Latar Belakang dan Beberapa Penerapannya. Jakarta: PT. Gramedia Pustaka Utama.

Trianto. (2012). Model Pembelajaran Terpadu. Jakarta: Bumi Aksara.

Ulva Dianasaril, R. M., \& Maruddin, F. (2018). NILAI Ph, ASAM LAKTAT DAN WARNA SUSU FERMENTASI DENGAN The Values of Ph, Lactid Acid and Color of the Fermented Milk Added with Red Dragon ( Hylocereus. (March 2019).

Widiasworo, E. (2017). Inovasi Pembelajaran berbasis life skill dan entrepreneurship. Yogyakarta: AR-RUZZ MEDIA. 